\title{
The Summa Halensis
}

\section{A Text in Context}

\begin{abstract}
The Summa Halensis was unprecedented in its size and complexity, realizing in many ways the full potential of the summa genre. The chapter assesses the Summa as an organic whole by examining the project in its intellectual and cultural context, and demonstrating several principles of organization that reflect its doctrinal commitments. The chapter further discusses the cultural meaning of writing a summa in early $13^{\text {th }}$ century Paris and the specific circumstances of the authorship of the Summa Halensis, which was written during a time of external and internal pressures for the Franciscan studium. It then considers the size and structure of the text compared with earlier summae, and briefly examines the enormous work of compilation which was invested in its composition, demonstrating the way ideas and doctrines guided structural choices in the text and vice versa.
\end{abstract}

Medieval theological Summae like the Summa Halensis are so rich and modular, that there is plenty of scope for any and every scholar to delve in and deeply study one specific topic or another, as it is presented in an individual treatise or even a quaestio, and to situate their discussion in relation to the history of the relevant doctrine, whether it be baptism, angelic speech, creation, or the vice of avarice. I shall not provide here any focused, topical study of this sort. What I rather aim to do, is to look at the Summa Halensis project from a distance, to assess its overall historical, cultural and intellectual context, and to shed some light on the threads that hold this massive text together, weaving an intricate relationship between its form and its matter.

It is a difficult task to evaluate the Summa genre to which the Summa Halensis belongs, insofar as it had developed by the first half of the $13^{\text {th }}$ century, for we have only partial evidence of the works produced during this period. For a work of this kind to survive into the modern era, it had to be popular enough in its time, and later continuously copied and promoted by an interested, committed line of copyists. In this regard, almost nothing has come down to us of the writings of the majority of the masters-especially the secular masters - we know were active in this period in Paris. ${ }^{1}$ In the case of those whose works are extant, we have a handful of questions or a fragment of a commentary only by virtue of the survival of unique manuscripts

1 For lists and biographical accounts of masters who worked in the first half of the $13^{\text {th }}$ century, see Nathalie Gorochov, Naissance de l'université: Les écoles de Paris d'Innocent III à Thomas d'Aquin (v. 1200-v. 1245) (Paris: Champion, 2012), and the appendix to Spencer E. Young, Scholarly Community at the Early University of Paris: Theologians, Education and Society, 1215-1248 (Cambridge: Cambridge University Press, 2014), 212-31. 
which contain them. The titles that have been given to certain texts such as the Summa Douacensis are an instant reminder that while a few anonymous specimens of the genre reached us in a single manuscript like the aforementioned, others were probably lost. $^{2}$

Until the time of Alexander and Hugh of St Cher's commentaries on Peter Lombard's Sentences, theology masters mostly expressed their views either in commentaries on the sacred page, or in the format of quaestiones. ${ }^{3}$ The task of compiling a Summa is a challenging one. Most medieval masters of theology were engaged in writing quaestiones, either as part of their engagement with a specific text like the Bible or Peter Lombard's Sentences, or in an isolated fashion. There was a long way to go, however, from producing numerous questions on various topics to their formation into an awe-inspiring, organized, monumental Summa. Some mastersperhaps only the minority-made this effort. Peter Lombard's Sentences provided general ideas for thematical principles of organization. ${ }^{4}$ Yet while the genre of Glosses and commentaries on Lombard evolved at the same time as Summa literature, and in time also included questions, as well as topics, that surpassed a close reading of the Lombard, the Summa genre was different. The authors of such texts did not even pretend to follow in the master's steps: the Summa was a magisterial act in its own right, subject to its own structural, doctrinal, and organizational principles.

In the times of Alexander, Summae had two conflicting aims: to be as comprehensive and as concise as possible. As a comprehensive text, a Summa could, at least in theory, make other texts redundant. Works such as the Filia magistri (1232-1245), a summary of the Sentences, chose the latter over the former, treating length as the 'mother of disgust'. ${ }^{5}$ Others chose the opposite approach. To hold everything together, meant to create a kind of a mirror of the field, thereby exploring its limits. The flexibility of the genre enabled compilers to expand the horizons of the theological project, and to richly embed it with philosophical notions. To compile

2 Glorieux argued that a large cluster of questions in MS Douai 434 comprise a Summa, which he edited in La "Summa Duacensis" (Douai 434): texte critique avec une introduction et des tables, ed. Palémon Glorieux, Textes philosophiques du Moyen Âge, 2 (Paris: Vrin, 1955).

3 Alexander of Hales, Magistri Alexandri de Hales Glossa in quatuor libros Sententiarum Petri Lombardi, 4 vols, Bibliotheca Franciscana Scholastica Medii Aevi, 12-5 (Quaracchi: Collegium S. Bonaventurae, 1951-7). Hugh of St Cher's commentary is extant in multiple manuscripts but has not been yet edited. A list of manuscripts is available in Barbara Faes de Mottoni, 'Les manuscrits du commentaire des Sentences d'Hugues de Saint-Cher,' in Hugues De Saint-Cher (+1263): Bibliste et theologien, ed. Louis-Jacques Bataillon, Gilbert Dahan, and Pierre-Marie Gy, Bibliothèque d'histoire culturelle du Moyen Age, 1 (Turnhout: Brepols, 2004), 273-95.

4 For an introduction to the tradition of commenting on the Sentences, see Philipp W. Rosemann, The Story of a Great Medieval Book: Peter Lombard's Sentences (Toronto: University of Toronto Press, 2007).

5 Rosemann, The Story, 33-7; Franklin Harkins, 'Filiae Magistri: Peter Lombard's Sentences and Medieval Theological Education "On the Ground", in Medieval Commentaries on the Sentences of Peter Lombard, ed. Philipp W. Rosemann (Leiden: Brill, 2015), 26-78. 
such a Summa was to narrate the world and history anew: neither following the narrative of Scriptures, nor hiding behind the Lombard, but to become masters in the full sense of the word.

The influential and significant masters of the 1220s, such as William of Auxerre, in the Summa aurea, and Philip the Chancellor, in his Summa de bono, employed this potential of the Summa genre in a manner more sophisticated and innovative than their predecessors. ${ }^{6}$ William of Auvergne, first a master and then an influential Parisian bishop, executed a gigantic, comprehensive theological project of a different sort, the magisterium sapientiale et divinale. ${ }^{7}$ In the 1230s, Roland of Cremona, the first Dominican master, compiled his Summa. None of these authors left, as far as we know, a commentary on the Sentences. Alexander of Hales, and later Hugh of St Cher, composed such a commentary, developing the genre as a means of expressing his own brief opinions and questions about issues posed by the Lombard, and as a basis for both the written and oral presentation of systematic thought. Like Hugh and other masters, Alexander also wrote long, highly elaborated disputed questions on a range of themes. Such writings, however, were not magisterial works. They were insufficient in size and scope both as a vehicle for delivering fully developed arguments, and as a symbol of magisterial maturity and prestige.

This was a time of ambitious, collective projects in all spheres of Western European civilization. In architecture, cathedrals were planned and constructed, which were ever bigger, higher, and more complex. In literature, from the 1210 s to the 1230s, several narrators took it upon themselves to complete the first immense prose cycle of the Arthurian legends (the 'Vulgate' cycle), masterfully weaving a myriad of scenes, intersecting plot lines and characters together. ${ }^{8}$ In the Dominican Parisian school, Hugh of St Cher and his colleagues aspired to write extensive commentaries or postillae upon the entire Bible and fashion innovative scholarly tools like correctoria and concordances. Vincent of Beauvais began working on his monumental 'mirrors': a series of encyclopedic works summarizing knowledge of nature (Speculum naturale), doctrine (Speculum doctrinale) and history (Speculum historiale).

The more ambitious the plans were, the more difficult it was to fulfill them. Towers collapsed; stories of eventful adventures were left unfinished. The authorship of the mirror of morals Vincent planned to write is doubted, and it exists in rare copies.

6 William of Auxerre, Summa Aurea, 7 vols, ed. Jean Ribaillier, Spicilegium Bonaventurianum, 16-20 (Paris: Editions du Centre National de la Recherche Scientifique (CNRS); Grottaferrata: Editiones Collegii S. Bonaventurae, 1980-7); Philip the Chancellor, Summa de bono, 2 vols, ed. Nikolaus Wicki (Bern: Francke, 1985).

7 Only a small segment of the Magisterium is edited. The old print version is flawed in many places but is still the most convenient way to consult the work: William of Auvergne, Guilielmi Alverni Opera Omnia, 2 vols (Paris: Johannes Dupuis, 1674).

8 On the prose vulgate cycle, see the introduction and essays in The Lancelot-Grail cycle: text and transformations, ed. William W. Kibler (Austin: University of Texas Press, 1994). 
Many of the Summae of this and the next generation remained incomplete. Philip the Chancellor's Summa de bono ends before addressing 'the good of glory'. Many questions promised in prologues for further sections were never actually written. Thomas Aquinas famously left his Summa incomplete after having a vision in which he suddenly perceived all his work 'as straw'.

Masters in the schools of the friars, with their abilities to organise collaborative projects, were better equipped than secular masters to execute such massive endeavors. But even then, it was a challenge to complete them. Pope Alexander IV's bull ordering the Franciscan studium in Paris to complete the Summa Halensis clearly illustrates the amount of assistance a master needed just to complete such a project. William of Melitona was ordered to gather all of the expert, sedulous assistants he might need from different provinces of the order. ${ }^{10}$ Between 1240 and 1248, Adam Marsh wrote a letter to William of Nottingham, the minister of England. He and another friar named William of Madelle spoke, he relates, about a certain order calling for friars from foreign provinces to come to the aid of the Parisian studium in this time of urgent necessity' (studio Parisiensi in presenti urgentia). The editors of the Chartularium Universitatis Parisiensis posed the possibility that this may refer to the state of the studium after the deaths of both Alexander and John in 1245. Yet the exact nature of the task discussed by the two-de investigandis expositionibus sacre scripture in libris originalibus Sanctorum, that is, to look through Patristic Biblical expositions-fits much better to the work on the Summa. ${ }^{11}$

But why invest so much energy? Thirteenth-century systematic theological works, such as commentaries on the Sentences or theological Summae, usually explicitly address the purpose of the theological enterprise as a whole. William of Auxerre, the distinguished author of the most influential Summa in the decades prior to the compilation of the Summa Halensis, and Godfrey of Poitiers, his contemporary Parisian master, listed three reasons for undertaking a reasoned discussion of the content of faith: 1 . to strengthen the faith with arguments; 2 . to be able to refute heretics; and 3. to confirm the faith of simple believers. ${ }^{12}$ An anonymous commentary in Vat. Lat. 691, which comes from the circle of John of La Rochelle and his contemporary Dominican master, Guerric of St Quentin, focuses only on the second aspect. ${ }^{13}$

9 Fontes vitae S. Thomae Aquinatis: notis historicis et criticis illustrati, ed. Domenicus Prümmer (Toulouse: Apud Ed. Privat, 1912), 43-4, 120, 193.

10 Chartularium Universitatis Parisiensis (henceforth CUP), 4 vols, ed. Emile Chatelain, Charles Samaran, and Émile A. van Moé (Brussels: Culture et civilisation, 1964; reprint of Paris: Ex typis fratrum Delalain, 1889-91), 1:328-9, \#286.

11 CUP 1:216, \#188.

12 William of Auxerre, Summa Aurea, Prol. (Ribaillier, 1:15); Godfrey of Poitiers, Summa (Avranches, Bibliothèque Municipale 121, fol. 2r).

13 On the attribution of this commentary, see Albert Fries, 'De commentario Guerrici de S. Quintino in libros sententiarum,' Archivum Fratrum Praedicatorum 5 (1935): 326 - 41; Jacques Guy Bougerol, 'La glose sur les Sentences du manuscrit Vat. Lat. 691,' Antonianum 55 (1980): 108-73; Jean-Pierre Tor- 
The warriors in this context are the doctors of theology, fighting for, and defending the faith against heresy, armed with the swords of authorities and the sharp spears of arguments. ${ }^{14}$ They rarely however addressed the motives for choosing a specific genre for their work, such as a Sentences commentary versus a Summa. Hugh of St Cher, following earlier authors, saw before his eyes students who were overwhelmed by the thought of reading the Bible and the fathers. The brevity of his Sentences was intended to ease the way for those who feared the enormous task of considering the large number of sacred books, and for those who lacked the strength to undertake it. ${ }^{15}$ The Filia Magistri, a short Summa which borrows its material from both William of Auxerre and Hugh of St Cher, and was contemporary with the Summa Halensis, emphasized, as mentioned earlier, its brevity and utility for students specifically. ${ }^{16}$

Philip the Chancellor took a different approach in his Summa de bono, by turning to the psychological context of learning and describing theological reasoning as key to perfecting the mind. The perfection of the practical intellect, he asserts in his prologue, belongs to the part of theology that deals with sapientia morum, while the perfection of the speculative intellect relates to the intelligentia questionum. His Summa, essentially a collection of questions, is of the second sort, and aims therefore for the perfection of the speculative intellect. ${ }^{17} \mathrm{~A}$ similar approach was taken by the anonymous author of a prologue to a commentary on the Sentences, which seems to come from the circle of Alexander. While the Bible perfects the affective parts of the soul, questions and arguments such as those found in the Sentences perfect the speculative aspects thereof. ${ }^{18}$

The authors of the Summa Halensis did not attach a prologue to this work: the general prologue found at the beginning of the Quarrachi edition is thought to be in fact the prologue for the third part. However, they devoted an entire introductory treatise to the status of theology and knowledge of God in Book 1. Curiously, this section does not address its general purpose, namely, the finis theologiae. As it discusses the Biblical style or mode of conveyance of knowledge, it gives the reader a strong impression that the modus of the sacred page is far from scientific. Unlike the human sciences, the sacred page does not employ divisions and definitions. As a sci-

rell, 'Introduction,' in Guerric of Saint-Quentin: Quaestiones de quolibet, ed. Walter H. Principe and Jonathan Glenn Black (Toronto: Pontifical Institute of Mediaeval Studies, 2002), 6-9.

14 Vatican City, Biblioteca Apostolica Vaticana, Vat. Lat. 691, fol. 1r.

15 Hugh repeats the Pseudo-Peter of Poitiers Gloss, whose text is translated at Rosemann, The Story, 43-51, see esp. 49.

16 Rosemann, The Story, 37.

17 Philip the Chancellor, Summa de bono, Prol. (Wicki, 1:4).

18 The text, intended as a prologue to a commentary to the Sentences, is edited in Jeanne BignamiOdier, 'Le manuscrit Vatican latin 2186,' Archives d'histoire doctrinale et littéraire du Moyen Âge 11 (1937): $133-66$. 
entia aimed at informing the affective parts of the soul, or desires, Scriptures or some parts of theology must use precepts, examples, narratives, exhortations, etc.

With such forms of knowledge, certitude is the result of personal experience. ${ }^{19}$ But it is not a coincidence that these questions speak about the sacred Scriptures rather than theology: in fact, they evade the problem. The hundreds of questions that follow this introductory discussion are written, without exception, in the first mode: they employ divisions and definitions, and stay away from precepts, narratives, exhortations, and the like. To explicate what the authors, perhaps intentionally, were not explicit about: while theology as a whole involves both the true and the good, the Summa does not. It aims at the perfection of the intellect alone, just as did that of Philip the Chancellor.

Alexander IV's idea regarding the utility of the work was more practical, if quite general. He wanted the work completed in order to provide a resource for advanced students, which was able to help them crush falsity with the weight of truth and irrefutable arguments. Aware perhaps of the overall cry for brevity in academic circles, he assured 'delicate readers' who might abhor its length, that its ongoing utility would make it seem short (prolixitatem quippe, si quam in eadem summa lector delicatus abhorret, studiosis vobis in ea sic reddit continua partium suarum utilitas brevem..$^{20}$

But there were more immediate political reasons to command the completion of the Summa Halensis. The existing contemporary testimonies, as well as the state of current research, cannot provide a certain, unbiased picture of Alexander's true standing among the masters before taking the habit. But, certainly, the studium could provide him with all the resources he needed to engage in this task, and to enhance his and the order's prestige. The renowned master William of Auxerre died in 1230. The 'great cleric of France', ${ }^{21}$ Philip the Chancellor, died in 1235 . Authoring such a Summa positioned Alexander as the unmatched heir to this line of philosophically informed, sophisticated Summists.

The studium definitely needed such a boost. The years in which the first parts of the Summa were written were a time of escalating tensions between the friars and the secular masters in the faculty and beyond it, tensions which would soon come to a head. Ten years earlier, a major strike of the masters and students tore apart the faculty, with most masters supporting the university's cause against the crown, the city and Bishop William of Auvergne, while others refused to suspend lectures. The Dominican master Roland of Cremona incepted during this crisis, giving the Preachers their first chair. ${ }^{22}$ In the beginning of the 1240s, during the work on the Summa Ha-

19 Alexander of Hales, Doctoris irrefragabilis Alexandri de Hales Ordinis minorum Summa theologica (SH), 4 vols (Quaracchi: Collegium S. Bonaventurae, 1924-48), Vol I, TrInt, Q1, C4, Ar1 (n. 4), pp. 7-8. 20 CUP 1:328-9, \#286.

21 Henri d'Andeli, Les dits d'Henri d'Andeli: Suivis de deux versions du Mariage des Sept arts, ed. and trans. Alain Corbellari (Paris: Champion, 2003), 65.

22 For a recent account summarizing these events, see Gorochov, Naissance, 397-459. 
lensis, ten opinions were condemned by a committee of masters including Alexander. Similar views could easily be found in Alexander's own writings. ${ }^{23}$ Matthew Paris believed the event was mainly meant to hold the mendicant orders in check, although the reasons for it have been debated. ${ }^{24}$ In this time of escalating tensions, compiling a Summa which demonstrated both the intellectual vigor and orthodoxy of the studium was a wise and indeed strategic move.

This was all the more true regarding its completion, as the tensions erupted a few years after Alexander and John's deaths in 1245. Already in 1250, Pope Innocent IV had to order the reluctant chancellor to give monks and friars the license to teach after they passed their exams. ${ }^{25}$ In 1253 the secular masters obligated the friar masters to subject themselves to the union's decisions, and to suffer exclusion from it if they would not do so, as they had done previously during the teaching strike. ${ }^{26}$ In July 1253, Pope Innocent IV had to demand once again that the friars be re-admitted to the union of masters and scholars that was the university. ${ }^{27}$

The constant papal attempts during the years between 1254 and 1256 to enact compromise and cooperation did not put an end to the conflict between the seculars and the mendicants, and accusations of heresy added fuel to the quarrels. The views of some Franciscans on the central place of their order in salvation history-Gerardo of Borgo San Donnino's eternal gospel in particular-put them under strong suspicions of heresy; Dominicans purged all their works once again of any residue of the opinions condemned in 1241 and renewed the condemnations in all provinces of the order. ${ }^{28}$ Less than a week after one of these Dominican orders was issued, Pope Alexander IV, a constant supporter of the friars, ordered William of Melitona to secure all the help he required and complete the Summa Halensis. Clearly, its completion was part of the strategy for defending the mendicants and especially their right to teach in this time of conflict. By a work such as the Summa, the friars would be able to reassert their full participation in the university's ideal of learning and their pure orthodoxy, pursuing Alexander's heritage. If Alexander of Hales is indeed the same Alexander who represented the university's cause back in 1230, the effect would be even stronger.

23 For an account of these condemnations and of Alexander's view concerning the first one, see Ayelet Even-Ezra, Ecstasy in the Classroom: Trance, Self and the Academic Profession in Medieval Paris (New York: Fordham University Press, 2019), 81-110.

24 Mathew Paris, Chronica maiora, vol. 1, ed. Henry Richard Luard (London: Longman, 1872); Mathew Paris, Matthew Paris's English History from the year 1235 to 1273, 3 vols, trans. John Allan Giles (New York: AMS Press, 1968), 1:476.

25 CUP 1:219, \#191.

26 CUP 1:242-4, \#219.

27 CUP 1:247-8, \#222.

28 On Gerardo de Borgo San-Donnino affair and condemnation of his writings see the literature cited under the entry of his name in Maarten van der Heijden and Bert Roest, 'Franciscan Authors, $13^{\text {th }}-$ $18^{\text {th }}$ Century: A Catalogue in Progress,' last modified 23 March 2019, http://users.bart.nl/ roestb/franciscan. 
Internal affairs of the order played a role in the decision to compile a Summa as well. The conflicting requirements of simplicity versus learning may not have plagued the order from its beginnings, and the break with the spirituals was still far in the future when the Summa was written. ${ }^{29}$ But these tensions were definitely felt, and they came to the fore only few years after Alexander took the habit. In 1239, after Elias' rule as minister general of the order, dominant friars promoted the clericalization and institutionalization of the order. The Parisian masters, particularly Alexander, were an integral part of this process, which provoked a sharp counter-response by many who saw this as ruining Francis' legacy of poverty and simplicity. A group of masters from the Parisian studium, including Alexander and John, was asked to provide a Gloss on the Rule, and handed it to Haimo of Faversham in 1241-2. At this time, Francis' Testament was only few years old. Well aware of his insistence in his text that nothing-Glosses included-should be added to his rule, they emphasized in the prologue that they had not added 'any new exposition or gloss to the rule, as suspected by "some condemners of pure intention who are overwhelmed by their zeal, to the danger and scandal of the friars". ${ }^{30}$ Members of this very group had just started working on the Summa.

In 1244, while the masters were working hard on the Summa in Paris, Thomas of Celano was commissioned to write the second legenda or Life of Francis. In it he devoted a cluster of chapters to the conflict between learning and simplicity. One anecdote ascribes to Francis the statement that a great cleric who wishes to join the order should, in a sense, get rid of his knowledge just like the rest of his possessions, and devote himself naked to Christ. ${ }^{31}$ Alexander must have seemed for several friars like a vivid example of one who did just the opposite, for the Summa splendidly showed off his prior knowledge. Its complex structure and subtle arguments are anything but simple: a blunt demonstration of the changing winds.

Whether or not one faction or the other was truer to the original spirit of the order's founder is not the issue here. There are different ways to be true to a vision. The more interesting question is whether Alexander, his collaborators and his immediate successors attempted to make a work that mirrored Francis' vision and the values of the order, or just be the best standard academic theologians they could be. They certainly say nothing explicit about these matters, a noteworthy absence in its own right. But are any distinctly Franciscan objectives intertwined in the fabric of the

29 On these historical processes and tensions, see Rosalind B. Brooke, Early Franciscan Government: Elias to Bonaventure (Cambridge: Cambridge University Press, 1959); Bert Roest, A History of Franciscan Education (c. 1210-1517) (Leiden: Brill, 2000); Bert Roest, Franciscan Learning, Preaching and Mission c. 1220-1650 (Leiden: Brill, 2015). On the particular stand of Franciscan theology masters, see Even-Ezra, Ecstasy in the Classroom, 151-6.

30 Expositio quatuor magistrorum super regulam fratrum minorum (1241-1242), ed. Livarius Oliger (Rome: Storia et letteratura, 1950), prol.

31 Thomas of Celano, Vita Secunda, \#146, in Legendae S. Francisci Assisensis saeculis XIII et XIV consciptae, Analecta Franciscana, 10 (Rome: Quaracchi, 1887), 241. 
text, in the views presented, and in the choice of subjects? To what extent does the Summa of Alexander, the converted master, bear a 'Franciscan character', and what does that exactly involve? In this connection, some topics come to mind more immediately than others: questions on voluntary poverty in the fourth part, as well as questions about Adam and the pre-lapsarian state in the second part, especially regarding property. The questions on beauty may echo an aesthetic sensitivity common amongst Francis and his followers. According to Parisoli, the treatise on laws forms the basis for articulating a distinctively Franciscan political theory. ${ }^{32}$

The fact that many views, tendencies and foci of interest are shared by the early Alexander and non-Franciscans like Philip the Chancellor, or rely heavily upon the Victorine tradition, should not be considered as a counter-argument to the notion of a distinctive Franciscan tone in the Summa. The character of a text is never only a matter of innovation: it is also a choice regarding whom to follow and whom to associate with. There was perhaps a reason why the formerly secular master Alexander took the habit, and Philip the Chancellor asked to be buried with the Franciscans. ${ }^{33}$ Alexander could follow William of Auxerre as many of his generation had, but on many occasions, he chose frequently a path closer to Philip and the second generation of the Dominican studium, Hugh of St Cher and Guerric of St Quentin. ${ }^{34}$ That said, a discussion of the Franciscan character of the Summa exceeds the scope of this essay, and requires a close examination of a series of issues in the Summa compared with its contemporaries. Lydia Schumacher devotes her recent book to argue for a decisive positive reply, and we hope it will stimulate discussion. ${ }^{35}$

\section{Compilation and Writing}

To truly understand the ambitious scope of the Summa, one should first look at its unprecedented number of questions-units. The chart below (Figure 1) compares it with two Summae of the same genre from earlier generations, which share its character and format, by contrast to works that display a different organizing principle, such as Philip the Chancellor's 'the good', or that are written in a different style, such as William of Auvergne's Magisterium, which was not composed of questions. The first is that of Praepositinus of Cremona, a master and chancellor in Paris at the be-

32 Luca Parisoli, La Summa fratris Alexandri e la nascita della filosofia politica francescana: riflessioni dall'ontologia delle norme alla vita sociale (Palermo: Officina di studi medievali, 2008).

33 According to Alberic de Troix-Fontaines, Philip was buried in the Franciscan chapel. Robert Lerner, 'Weltklerus und religiöse Bewegung im 13. Jahrhundert: Das Beispiel Philipps des Kanzlers,' Archiv für Kulturgeschichte 51 (1969): 94-108.

34 On Alexander and Philip sharing many views see Even-Ezra, Ecstasy in the Classroom, 196 and passim.

35 Lydia Schumacher, Early Franciscan Theology: Between Authority and Innovation (Cambridge: Cambridge University Press, 2019). 
ginning of the $13^{\text {th }}$ century. The other is the 'Golden' Summa of William of Auxerre mentioned above, composed roughly a generation later. The numbers below represent the approximate count of question-units (unit defined as cluster of question-arguments-objections-solution-replies). ${ }^{36}$ The count provided is necessarily inaccurate in the first two Summae, however, because sometimes it is difficult to determine when a new unit begins, especially in the earlier two cases; this itself shows a growing awareness order in itself. Nevertheless, the chart below gives the general idea of the relationship between the works in terms of size.

\section{Estimated number of questions according to books}

Praepositinus $\square$ William of Auxerre $\square \mathrm{SH}$

1380

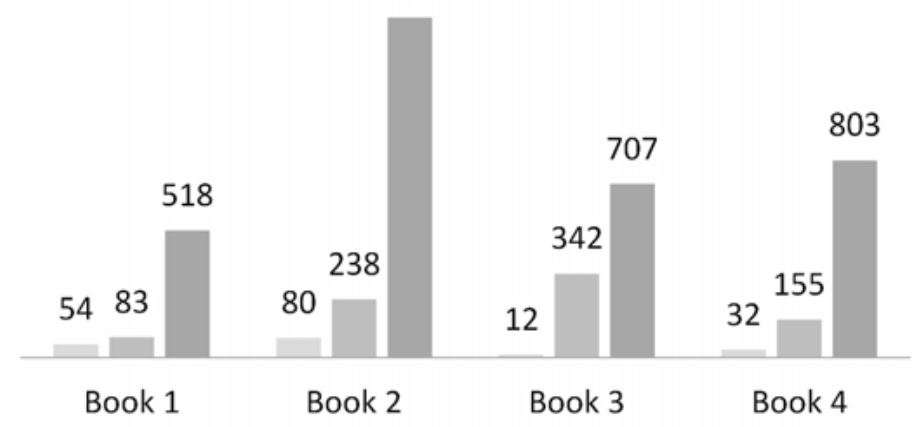

Figure 1

While the general picture is clear, it is more difficult to compare the relative volume of specific treatises or subjects, for many issues were transferred from one category to another in the endless play of scholastic authors with principles and forms of organization. Let us, therefore take also as an exemplary case study the subject of 'God's knowledge' and compare its inner division in the Summa aurea and in the Summa Halensis. The prologue of the Summa aurea announces 12 questions without specific sub-divisions. In practice, there are seven questions; the third, on predestination and reprobation divides into five sub-questions. We may also add one question about providence. The Summa Halensis has a total number of 109 questions, ar-

36 Numbers are necessarily approximate and inaccurate regarding the first two cases, but the tendency is clear enough. For Praepositinus, I have relied upon the list of questions attached to Paris, Bibliothèque Nationale de France, Lat. 14526, fol. 1v. For William of Auxerre's estimation, I used the list of contents of the critical edition, which is usually accurate, except for few cases, mostly due to William's style flowing freely from one question to another and the manuscripts' titles. 
ranged in a seven-tiered hierarchy of sectio-quaestio-titulus-membrum-capitulum-articulus-[unspecific roman number].

How did such expansions occur? Questions relating to the subject were gathered from the productive masters of the studium: Alexander, Jean of La Rochelle and others. Some were copied verbatim (the questions on the eternal word, for instance into 1:419-26); some went through thorough redaction, or were used only partially. Others were not included at all. Indeed, even when there were relevant Alexandrian materials, they were not always chosen to be included. ${ }^{37}$ Entire treatises originating in early, independent contexts, such as de fato or de libro vitae were incorporated into the program. Furthermore, the Summa reproduced large sections of John of La Rochelle's works like the Summa de anima. Yet at the same time, many new sections were written especially for this occasion, to put flesh on the larger outline and architectural plan.

Another form of expansion was the result of minute analysis of one question into separate aspects by means of subtle distinctions. Where William of Auxerre asks one question: 'How God knows everything', the Summa Halensis proposes four: 'How God knows everything praesenter, simul, perfecte, immutabiliter. ${ }^{38}$ The hierarchical organization, which categorised subjects anew, also invited examinations of a general nature, absolute spectatis or in communi. Common features of a group of subjects were then each examined in turn. Dealing jointly with the common features of a group has a great advantage, as Aristotle already taught us, for then there is no need to repeat and address the same problem for each separate question. But it also generates new questions of a higher order. Thus, while earlier Summae discussed created beings with little attention to the problem of creation in general, the Summa Halensis has an entire cluster of such general questions. Regarding angels, rather than asking only about their movement or cognition, we have an introductory section on their potency as such. Another example, as I have pointed out elsewhere, was the decision to arrange topics gathered from here and there under a discussion of freely given, non-sanctifying grace, which resulted in new questions about the nature of this type of grace. ${ }^{39}$ Such processes bring us to the intriguing issue of systematic schemes of inquiry and the way architecture influences the production of many new building blocks.

37 Victorin Doucet, 'Prolegomena in librum III necnon in libros I et II "Summae Fratris Alexandri”,' in Doctoris irrefragabilis Alexandri de Hales Ordinis minorum Summa theologica, vol. 4 (Quaracchi: Collegium S. Bonaventurae, 1948), 307; cf. 167.

38 William of Auxerre, Summa Aurea, l. 1, t. 9, c. 1 (Ribaillier, 1:177); SH I, P1, In1, Tr5, S1, Q1, C3-6 (n. 177-80), 261-5.

39 Ayelet Even-Ezra, 'The Conceptualization of Charisma in the Early Thirteenth Century,' Viator 44 (2013): 151-68. 


\section{The Architectural Plan: Structure and Doctrine}

The most challenging aspect of the work of compilation involved ensuring that the enormous quantity of questions and materials were not merely piled one on top of the other but organized into a highly complex and well-thought out hierarchical structure. The Summa Halensis represents a fully-fledged stage in the transformation of the genre from a collection of questions, the links between which are either not explained at all or only in a few words, to the Summa with a carefully reasoned structure that is also explicitly revealed to the reader in the form of titles and prologues. This is evident in an increasing number and volume of introductory remarks and prologues, and in the number of layers major texts entailed. Master Martin (ca. 1200) sometimes justifies the order of his questions, in formulas such as 'Cum nomina effectuum transumantur ad causam, et quelibet fuit a deo, queritur an omnium nominibus (...)' or 'Cum nomina creaturarum ad nominandum creatorem transumantur, queritur quomodo vel in qua significatione de deo predicentur. Solutio (...).' Occasionally, there are comments about the common theme of several questions, like 'duo sunt dumtaxat predicamenta theologica, substantia scilicet et relatio. Nonullas autem quaestiones quae tuta hec fieri solent prout nobis occurent prosequentur. Deo autem idem est prescientia et scientia et essencia. ${ }^{40}$ A similar use of linking phrases is attested in Geoffrey of Poitiers' Summa, which includes only three levels (bookquestion-subquestions), and which sometimes has introductory sentences such as, 'nunc redeamus ad illa que circa ecclesiam aguntur et primo de symonia dicamus (...). ${ }^{41}$

By the time we arrive to the Summa aurea of William of Auxerre, attention to structure becomes more evident and the structure itself more complex. Ribaillier suggests that 'l'auteur de la Summa aurea a pris soin lui-même de regrouper ces questions en sections et en sous-sections aisément discernables, chacune d'entre elles étant en effet précédée d'introductions et de sommaires où sont enumérées les questions qui en font partie. ${ }^{42}$

Subdivision or grouping became an integral part of the work of editing, and groupings differed greatly between different recensions, while the order of the units remained the same. ${ }^{43}$ Samples show that the maximum number of subdivisions in the Summa aurea is around five: liber-tractatus-capitulum-capitulum(2)-articulus. The structure and order of questions are always reasoned, with introductory phrases linking one to another, like: 'since angels look at the mirror of eternity as do prophets, we shall now discuss prophecy,' and offer a detailed plan of the issues to follow.

40 Toulouse, Bibliothèque Municipale 209, fols 3ra, 4ra and 10va, respectively.

41 Godfrey of Poitiers, Summa (Avranches, BM 121, fol. 153rb).

42 Jean Ribaillier, 'Introduction,' in William of Auxerre, Summa Aurea (see above, n. 6), 1: 10.

43 Ribaillier, 'Introduction,' 1:9-10. 
Philip the Chancellor's Summa de bono, a source of inspiration in terms of both doctrine and style for the Summa Halensis team, provides reasoned linking phrases and detailed prologues as well. The number of layers rises to more than seven towards the end of the work, according to the modern edition. The question, De distinctione symbolorum, for instance, is located thus in the general structure: De bono gratie $\Rightarrow>$ de bono gratie in homine $\Rightarrow>$ de gratia gratum faciente $\Rightarrow>$ de virtutibus theologicis $\Rightarrow$ de fide $\Rightarrow>$ de symbolis $=>$ de distinctione symbolorum. Looking at the prologues, rather than their fulfillment in the text, further subdivisions are revealed. The Summa Halensis follows this growing complexity with an average of ten such layers.

The super-scheme of the Summa followed the basic fourfold structure of exitusreditus, addressing 1 . God, 2. creation, 3. Christ and grace, and 4. sacraments and last things. But a systematic investigation of theology as any other topic usually does not proceed in one line: it is more like a web, each subject connected to many others. One line of inquiry raises a throng of related questions that could nevertheless be raised on another occasion as well. The editors had to decide on the best place to discuss a matter, then labored to refer readers to the places where such a question could also be assessed. 'Consequenter quaerendum esset $\mathrm{X}$ sed istud reservabimus inquirendum, cum quaretur de Y. ${ }^{44}$ Cross-references in sources should have been removed; links were removed and added; a diligent effort was needed to avoid repetitions and tell that to the reader 'omissa vero Q. utrum ( ... ), eo quod ipsa satis datur intelligi ex praemissa'. Some subjects indeed recur but received different treatments in different contexts, ${ }^{45}$ at times unintentionally, at times seemingly knowingly. The style should have been unified, and the doctrinal positions coherent. ${ }^{46}$ Each of the endless details of editing left marks, in the forms of undeleted references, incorrect ones, or textual or thematic repetitions. References for planned tractates were inserted, but these were never written. Prologues delineating a plan were sometimes not reedited and updated according to the actual fulfillment of that plan.

Apart from the aesthetic attraction such complex structures afford the intellect, they embody doctrine. It is beyond the scope of this short article to explain in detail all the doctrinal ideas behind structural schemes that dictate the intricate structure of the Summa Halensis. I will limit myself therefore to two detailed examples and mention briefly two others.

The first case pertains to a constant emphasis on the distinction between reality and language, as historically linguistic-oriented theology is moved to the background in favor of new metaphysical theology. This is exemplified in the approach to the divine realm which is taken in the first book of the Summa Halensis. In Summae of the first decades of the century, a linguistically-oriented approach dominates the discussion, which develops through questions about the applicability of names, adjectives

44 For examples, see Doucet, 'Prolegomena,' 320.

45 Doucet, 'Prolegomena,' 321.

46 On style coherence see Doucet, 'Prolegomena,' 326-32; on doctrinal coherence see 332-7. 
and other predicates to God. Master Martin, for instance, deals with the Manichean doctrine of two principles at the beginning of his first book, but then turns to the meaning of names. He sets off from the predicate ubique, for instance, to engage in a discussion of the divine presence in the world and in sinners' hearts. ${ }^{47}$ The author of Ne ad mensam, an anonymous Summa of the beginning of the $13^{\text {th }}$ century turns just after his prologue to consider 'names' that relate to the divine unity and to the different persons of the Trinity. ${ }^{48}$ Godfrey of Poitiers includes in his prologue proofs for God's existence and simplicity, but then moves on to a series of questions inspired by language, interspersed with more thematically-arranged titles: essential adjectives and relative adjectives; then to a question on whether the Father and the Holy Spirit are one; to dictiones; the name Jesus, essential names; the proposition 'God generates god'; etc. William of Auxerre's Summa aurea also mixes names and issues, but names and adjectives appear later. First, that God is one and immutable, 2. the number of persons, 3. the names that are being said about God, including essential names 4. adjectival names 5. the name 'persona' 6. notiones 7. and then again essential names, under the auspices of which issues such as omnipotence and predestination are considered.

The Summa Halensis, however, proposes a clear-cut distinction between heart and mouth, between divine reality itself and the names we use to describe it. The introduction to the first inquiry of the first book reads thus:

Cuius inquisitionis duae sunt partes, secundum verbum Apostoli, Rom. 10:20: "Corde creditur ad iustitiam, ore autem confessio fit ad salutem.” Est igitur inquisitio bipartita de Unitate et Trinitate deitatis: prima de ipsa re, quae est Unitas Trinitatis ordinata ad credulitatem cordis; secunda de nominatione ordinata ad confessionem oris, ut sciamus quod credimus, confiteri locutionibus catholicis et veris. ${ }^{49}$

And the introduction to the second part of the first book of the Summa Halensis:

Inquisitis in praecedentibus iis quae spectant ad fidem divinitatis et Trinitatis, procedimus ad inquisitiones eorum quae pertinent ad confessionem eiusdem sacratissimae Unitatis et Trinitatis; ad quod prosequendum ipsius adiutorium invocamus. Modum autem inquisitionis eius erit talis: Ut primo ponamus inquisitiones quasi introductorias circa divina nomina in generali; se-

47 For a list of his questions, see Richard Heinzmann, Die "Compilatio quaestionum theologiae secundum Magistrum Martinum" (Munich: Hueber, 1964).

48 Ne ad mensam (Florence, Biblioteca Medicea Laurenziana, Plut. 20.38), the capitula of the introductory section on the Scriptures end in fol. 3r. For a list of the questions and an introduction to the text, see François Henquinet, 'La Summa Florentina Ne ad mensam du début du XIIIme siècle,' Antonianum 22 (1947): $125-76$.

49 SH I, P1, In1, prol., p. 39: [Concerning this inquisition there are two parts, according to the word of the Apostle in Roman 10:20, "by the heart one believes and is justified, by the mouth one confesses and is saved." There is therefore a bi-partite inquiry concerning the unity and Trinity of the deity: first of that matter, which is the Unity of the Trinity leading to the belief of the heart; and second is the naming [of the Trinity] leading to the confession of the mouth, so that we know that we believe, and confess by true and catholic words]. 
cundo descendamus ad inquisitionem nominum in speciali; tertio vero colligamus nominum differentias simul, suppositis regulis quibus universaliter absque errore possimus enuntiare quod de sancta Trinitate credimus locutionibus catholicis et veris. ${ }^{50}$

Naturally, such a distinction involved the repetition of arguments and topics, but it drew a clear line between addressing the divine essence on the one hand, and topics like the name qui est on the other. The separation of the topics resulted in further the proliferation of questions to fill out the categories of names designating the divine essence, power or knowledge, and to further clarify whether the name in question refers to the actual divine object. This same structural tendency to address the res before its verbal representation is repeated in discussions of smaller scale. Earlier questions on faith started from Paul's definition of faith in Heb. 11:1. But the treatise on faith in the Summa Halensis changes the usual order of earlier treatises by dealing first with faith secundum rem, that is, its essence as a mental, grace-given and meritorious habit and virtue, and only then secundum diffinitionem, explaining its various definitions. ${ }^{51}$

Another case of structure according with doctrine is seen as the Summa Halensis employs a three-fold method of treating cognition, studying it first in itself; then in terms of its object-God, the unchanging truth; then in its different subjects. The latter category may discuss the relevant potency of the soul in which knowledge is located, as well as subjects like Christ, children, Adam, etc. This subject-habitus-object triad deeply resonates with Alexander's general view of cognition and the soul, as well as his doctrines about the real object of faith (divine truth rather than the articles of faith), and on mediation in the beatific vision. This understanding of faith and cognition in general, including that of beatified souls, as a habit distinct from the potency of the soul, had strong implications regarding the hotly disputed issue of the immediate vision of God in heaven. ${ }^{52}$

The compilation of the Summa Halensis was a significant cultural act in the intellectual, religious and political climate of the early $13^{\text {th }}$ century. It aimed to supersede earlier Summae by offering a spectacle of scholasticism and to establish the status and legitimacy of the burgeoning Franciscan studium at Paris in difficult times,

50 SH I, P2, In1, Tr1, p. 491: [From the proceeding inquiry concerning those things which pertain to faith in the divinity and in the Trinity, we produced to an inquiry concerning those things which pertain to the confession of that most holy unity and Trinity. This [inquiry] must be pursued with the help we will invoke. The mode however of this inquiry will be such that we must first undertake certain introductory inquiries concerning the divine name in general; secondly, we will descend to consider the name in particular; third we will gather different names together in one place, laying down rules by which we can universally and without error speak of the Holy Trinity in which we believe with words that are true and catholic]. This third part was never written.

51 For a detailed discussion of the distinction secundum rem/diffinitionem in its intellectual context see Ayelet Even-Ezra, 'Blind Men Speaking of Colors: Paul's Recollection and the Self-Image of Early Thirteenth-Century Theologians,' Harvard Theological Review 107 (2014): 425-46.

52 Even-Ezra, Ecstasy in the Classroom, 81-110. 
during which the order was subject to external and inner pressures. Its significance for the history of scholastic writing methods and textual approaches cannot be underestimated. The wealth of materials from the Franciscan studium-the Gloss, questions in different levels of redaction-as well as many minor errors resulting from the editing process, allow for tracing the process of its construction. Studying these materials, one can enter the scholastic laboratory and understand the meaning of such a collective scholarly effort, and perceive the beauty of its compilation, as doctrines dictate structural decisions, and those decisions in turn support the development of new ideas and the clarification of others. 